\title{
Unsustainable harvest of water frogs in southern Turkey for the European market
}

\author{
Kerím Çiçek, Dínçer Ayaz, Murat Afsar, Yusuf Bayrakci \\ Çíğdem Akin Pekşen, OĞuzkan Cumhuríyet, İlhan Bayram İsmaíl \\ Melodí Yenmiş, Erdal ÜstündaĞ, Cemal Varol Tok \\ C. CAN BİLGin and H. Reşìt AKÇAKAYA
}

\begin{abstract}
Frogs have been harvested from the wild for the last 40 years in Turkey. We analysed the population dynamics of Anatolian water frogs (Pelophylax spp.) in the Seyhan and Ceyhan Deltas during 2013-2015. We marked a total of 13,811 individuals during 3 years, estimated population sizes, simulated the dynamics of a harvested population over 50 years, and collated frog harvest and export statistics from the region and for Turkey as a whole. Our capture estimates indicated a population reduction of c. $20 \%$ per year, and our population modelling showed that, if overharvesting continues at current rates, the harvested populations will decline rapidly. Simulations with a model of harvested population dynamics resulted in a risk of extinction of $>90 \%$ within 50 years, with extinction likely in c. 2032. Our interviews with harvesters revealed their economic dependence on the frog harvest. However, our results also showed that reducing harvest rates would not only ensure the viability of these frog populations but would also provide a source of income that is sustainable in the long term. Our study provides insights into the position of Turkey in the 'extinction domino' line, in which harvest pressure shifts among countries as frog populations are depleted and harvest bans are effected. We recommend that harvesting of wild frogs should be banned during the mating season, hunting and exporting of frogs $<30 \mathrm{~g}$ should be banned, and harvesters should be trained on species knowledge and awareness of regulations.
\end{abstract}

KeRiM ÇiçEK (Corresponding author, (D) orcid.org/0000-0002-6753-0757), Dinçer Ayaz, Yusuf Bayrakci, OĞuzkan Cumhuriyet, İlhan Bayram İsmail and Melodi Yenmiș Zoology Section, Department of Biology, Faculty of Science, Ege University, 35100, Izmir, Turkey. E-mail kerim.cicek@ege.edu.tr

Murat Afsar Department of Biology, Faculty of Arts and Sciences, Celal Bayar University, Manisa, Turkey

Çï̆dem Akin Pekșen Molecular Biology and Genetics Department, Science and Literature Faculty, Başkent University, Ankara, Turkey

ERDAL ÜstÜNDAĞ Republic of Turkey Ministry of Food, Agriculture and Livestock, General Directorate of Fisheries and Aquaculture, Ankara, Turkey

Cemal Varol Tok Department of Biology, Faculty of Arts and Sciences, Çanakkale Onsekiz Mart University, Çanakkale, Turkey

C. Can Bilgin, Department of Biology, Middle East Technical University, Ankara, Turkey

H. Reșit AкÇAKaya Department of Ecology and Evolution, Stony Brook University, Stony Brook, New York, USA

Received 21 November 2018. Revision requested 14 January 2019.

Accepted 13 February 2019. First published online 13 May 2020.
Keywords Amphibian conservation, Anatolian water frog, extinction domino effect, frog harvest, Pelophylax, sustainable use, Turkey, wildlife trade

Supplementary material for this article is available at doi.org/10.1017/So030605319000176

\section{Introduction}

T arvest of wild animal and plant populations globally 1 for food, wildlife-based medicines, and pets threatens many species (Sodhi et al., 2004; Karesh et al., 2005; Worm et al., 2006; Gratwicke et al., 2010). The global trade in wildlife products is worth USD billions each year (Chan et al., 2015; Scheffers et al., 2019). Demand for wildlife products increases with human population growth and the expansion of economies of historically poor countries (Baker et al., 2013) and there is a critical need to develop management guidelines to sustain both wildlife and human populations in such countries.

Amphibians are among the most threatened animal groups (Stuart et al., 2004; Pavajeau et al., 2008; Gilbert et al., 2012), affected by a variety of factors, including environmental contamination (Boone \& Bridges, 2003), habitat loss (Alford \& Richards, 1999), global climate change (Kiesecker et al., 2001), diseases (Daszak et al., 2003; Gratwicke et al., 2010; Gilbert et al., 2012), chemicals (Gibbons et al., 2000; Houlahan et al., 2000; Warkentin et al., 2008), invasive species (Kats \& Ferrer, 2003; Altherr et al., 2011) and overharvesting (Schlaepfer et al., 2005). The underlying factors and causes of the decline of amphibians are complex and may be synergistic.

Trade in frogs is a global business: the USA and European Union are the largest importers, Indonesia and China are the main exporters, and the leading re-exporting country is Belgium (Warkentin et al., 2008; Altherr et al., 2011; Gerson, 2012; Musing et al., 2018) The economies supplying frog exports have shifted over time as a result of overharvesting: harvest bans to halt population declines can shift harvest pressure to other countries, a phenomenon termed the 'extinction domino effect' (Altherr et al., 2011). Legislative regulation is an effective way to protect wild populations by reducing harvest pressure to sustainable levels (Smith et al., 2018); for example, legislation to reduce trade 
in two frog species resulted in the recovery of the overexploited populations (Altherr et al., 2011).

Turkey is an important source country the for frog trade. Although there is no domestic consumption except in some restaurants catering for tourists, harvesting of wild frogs to satisfy international demand is expanding. Anatolian water frogs (Pelophylax spp.) form a species complex comprising at least two, and possibly up to five, closely related species (Akın et al., 2010; Plötner et al., 2010). These species have been harvested for $>40$ years (Akın \& Bilgin, 2010; Kürüm, 2015): Turkey exports nearly $700 \mathrm{t}$ of frogs annually, a trade that is worth nearly USD 4 million (Kürüm, 2015). During 1999-2009 Turkey was the third leading frog leg supplier to the European Union, with $4 \%$, after Indonesia (84\%) and Viet Nam (8\%) (Altherr et al., 2011).

Despite the threatened status of amphibians worldwide, and the importance of wildlife trade as a threat to species, few studies have quantified the impact of trade on the viability of amphibian populations. In addition, there are no population-level studies of the frog harvest in Turkey despite the country's importance in this trade. Here we assess the current population status of Eastern Mediterranean Anatolian water frogs (Pelophylax spp.), which are heavily harvested in the Seyhan and Ceyhan Deltas in Adana province. We (1) analyse the dynamics of a harvested frog population, (2) quantify the impact of harvest on the viability of the frog population, (3) make projections of frog harvest and viability under different future harvest regimes, and (4) make recommendations for conservation of Anatolian water frogs and for the future of the frog trade. Our assessment highlights the need for reconsideration of national conservation measures and certification of animals harvested from the wild that enter the international market.

\section{Methods}

\section{Surveys}

Initially, we surveyed Seyhan and Ceyhan Deltas in southern Turkey to determine the current status and harvest of frogs. We interviewed harvesters and exporter company managers, and selected survey locations in areas where the species was being harvested regularly (harvesters collect frogs from natural habitats, intermediaries organize the harvesters according to the demands of exporters, and exporting companies process the frogs). We then conducted field surveys during February-April (spring), June-August (summer) and October-November (autumn) in 2013, 2014 and 2015. We surveyed in a total of 10 locations in three macrohabitats: five ponds, three irrigation canals and two streams. Sampling was by four surveyors, who captured frogs during night-time by hand or with a fishing net (the methods used by harvesters). We determined the sex of each individual by secondary sexual characteristics, measured snouth-vent length with a caliper to the nearest $0.01 \mathrm{~mm}$, used a digital scale to record weight to the nearest $0.1 \mathrm{~g}$, applied a mark with a visible implant elastomer (Northwest Marine Technology, Inc., Shaw Island, USA; Çiçek, 2009; Çiçek et al., 2011), and then released each individual at its point of capture within 30-40 minutes. Before marking, we applied a local anaesthetic (ethyl chloride) to the body surface of the implant and after marking we applied a broad spectrum pomade (a mix of Furacin, Bacturaban and Stafine pomade) to prevent infection. Ethyl chloride is widely used, in the form of a topical anaesthetic spray, to decrease pain from needle puncture during injection procedures (Polishchuk et al., 2012), and produces instant skin anaesthesia (Armstrong et al., 1990).

\section{Demography}

We surveyed four times in each of the three seasons in all 3 years, giving 36 samples in each of the 10 locations. During each survey we recorded previously captured, marked and released individuals, and we marked and released all other individuals. We created capture histories for all individuals to estimate population parameters using MARK 8 (White \& Burnham, 1999; Cooch \& White, 2017) and estimated population size (assuming a closed population within a season) using model h (heterogeneity) in CAPTURE (Otis et al., 1978; White et al., 1982). We calculated apparent annual survival rates $(\phi)$ using the Cormack-Jolly-Seber model (Cormack, 1964; Jolly, 1965; Seber, 1965), and used Akaike's information criterion for model selection.

\section{Population viability analyses}

We developed a stochastic, density-dependent, matrix model with two stages, juvenile and adult, and a time step of 1 year. We set the age of first reproduction at 2 years, and parameterized the matrix model according to post-reproductive census:

$$
\begin{array}{ll}
0 & F \times S_{a} \\
S_{j} & S_{a}
\end{array}
$$

where $S_{\mathrm{a}}$ and $S_{\mathrm{j}}$ are annual survival probabilities of adults and juveniles, respectively, and $F$ is annual fecundity of adults (number of daughters per female per year). Thus, the element of the matrix representing reproduction $\left(F \times S_{\mathrm{a}}\right)$ incorporates survival of adults from the census in the previous year to breeding. Lacking a direct estimate of $F$, we calculated the product $F \times S_{\mathrm{a}}$ as the number of female juveniles in year $t$ per adult female alive in year $t-1$ (Table 1). The sex of juveniles cannot be determined, so we assumed $50 \%$ females at birth. Survival rates $S_{\mathrm{j}}$ and $S_{\mathrm{a}}$ 
TABLE 1 Parameters of the matrix model for the harvested population of Anatolian water frogs (Pelophylax spp.) in southern Turkey.

\begin{tabular}{|c|c|c|c|c|c|}
\hline \multirow[b]{2}{*}{ Year } & \multicolumn{2}{|l|}{ Survival rates } & \multicolumn{3}{|l|}{ Reproduction } \\
\hline & Juvenile $\left(S_{\mathbf{j}}\right)$ & Adult $\left(S_{\mathrm{a}}\right)$ & Number of adult females ${ }^{1}$ & Number of juveniles $^{1}$ & $F \times S_{\mathrm{a}}^{2}$ \\
\hline 2013 & 0.430 & 0.576 & 1,758 & 1,588 & \\
\hline 2014 & 0.331 & 0.612 & 1,680 & 1,872 & 0.532 \\
\hline 2015 & 0.288 & 0.498 & 1,389 & 770 & 0.229 \\
\hline Mean $^{3}$ & 0.350 & 0.562 & & & 0.381 \\
\hline Mean, corrected for emigration ${ }^{4}$ & 0.400 & 0.612 & & & \\
\hline Standard deviation & 0.073 & 0.058 & & & 0.214 \\
\hline
\end{tabular}

${ }^{1}$ Calculated with CAPTURE (maximum of the estimates for the three seasons).

${ }^{2}$ Calculated by dividing number of juveniles in a year by the number of adults in the previous year (see text for details).

${ }^{3}$ Survival rates are before correcting for emigration (i.e. apparent survival rates).

${ }^{4}$ Upper bound of mean survival rate, corrected by assuming $5 \%$ emigration (see text for details).

are based on the apparent survival rates $(\phi)$ calculated using the Cormack-Jolly-Seber model, but modified as follows. As this model cannot distinguish between emigration and mortality, apparent survival rates underestimate true survival to a degree dependent on emigration. We did not have data on emigration (or data that would allow a spatial Cormack-Jolly-Seber model). Based on the high site fidelity and the typical home range size of amphibians (Smith \& Green, 2005) compared to the size of our sampling areas, we assumed the emigration rate to be $0-5 \%$, and estimated survival rates $S_{\mathrm{j}}$ and $S_{\mathrm{a}}$ as the sum of the corresponding apparent survival rate and emigration rate. We used annual total population sizes $(N)$ calculated using CAPTURE as the initial population size in the population viability analysis. For all model parameters we pooled the data from the five of the 10 locations that had harvest pressure. We incorporated natural temporal variability (using the estimated standard deviations between years), demographic stochasticity and ceiling-type density-dependence (Akçakaya, 1991, 2013). Carrying capacity was set at half the observed population size (because we modelled only females). We simulated the dynamics of a harvested population for 50 years and 1,00o replicates (iterations) using RAMAS Metapop (Akçakaya, 2013).

\section{Modelling harvest impacts}

To explore the effects of harvest on population dynamics, we constructed a model of a non-harvested population. Because we did not have sufficient data from non-harvested areas, we assumed that our catch effort and efficiency were comparable to harvest effort and efficiency, and inferred survival rate in a non-harvested population $\left(S^{\prime}\right)$ based on our catch rates. This is a reasonable assumption because we used the same effort and methods for catching as those used by harvesters. However, harvesters may be more efficient than we were and thus we consider our catch efficiency to be a minimum bound of the efficiency of actual harvest. To calculate survival rate in a non-harvested population $\left(S^{\prime}\right)$, we assumed that natural mortality $(1-S)$ and mortality as a result of harvest $(H)$ are independent. In this case, survival rate $(S)$ in a harvested population is $S=S^{\prime}(1-H)$. Thus, survival rate in a non-harvested population is $S^{\prime}=S /(1-H)$. Here, $H$ is the proportion of individuals of a pre-harvest population that are killed by harvest. Since the data we have is the ratio, $T$, of the number of harvested individuals to the post-harvest population size (i.e. population already reduced by harvest), we calculated harvest mortality as $H=T /(1+T)$. To explore the impact of different harvest levels, we developed models with estimated survival rates for a non-harvested population, and ran simulations with harvest mortality varying from o to the value we estimated for the study populations. Because the type of density dependence may influence the impact of harvest, we used two types: a ceiling model, and a contest-type model (Akçakaya et al., 2007; see Results for details).

\section{Harvesting history and export statistics}

Frog trade data were obtained from the Turkish Statistical Institute (TÜIK). We also checked newspapers for trade news, most of which show illegal harvesting. This helped us supplement the statistical reports with information on illegal and off-the-record harvesting. In addition, during fieldwork we talked to exporting companies, local people and harvesters about their businesses and livelihoods (Supplementary Material 1).

\section{Results}

Demography, population viability analysis and harvest modelling

During the 3 years of fieldwork we captured and marked a total of 13,811 Anatolian water frogs, of which 10,295 were adults. The mean weight of all sampled frogs was $19.46 \mathrm{~g}$; only $19 \%$ of the captured individuals were $>30 \mathrm{~g}$, which is the minimum weight at which frogs may be harvested 


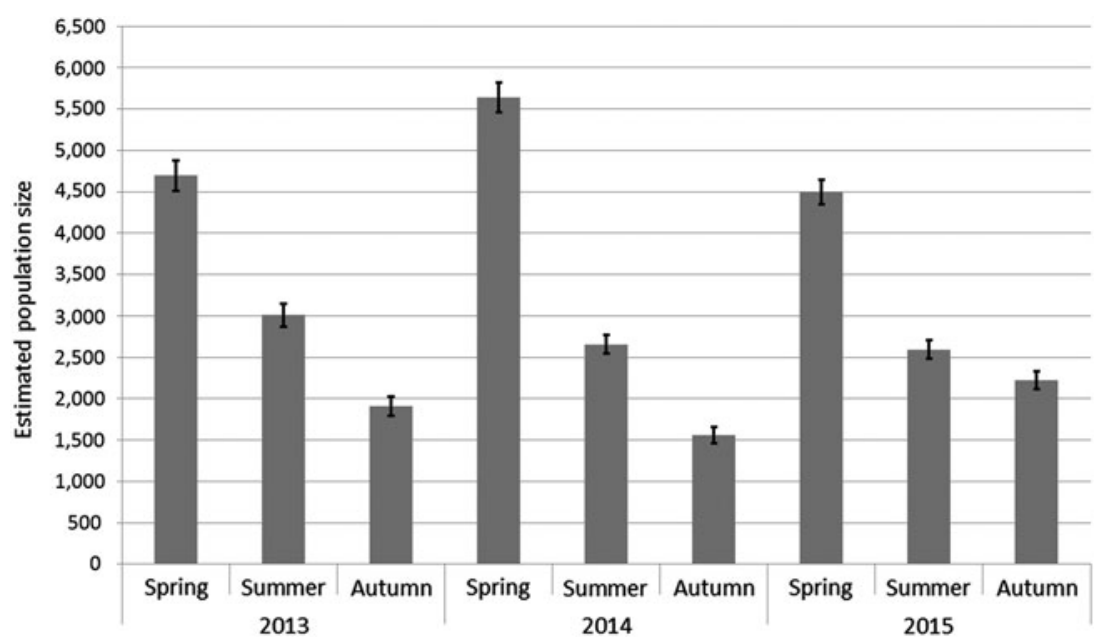

FIG. 1 Seasonal estimates of population size of Anatolian water frogs (Pelophylax spp.) in the sampling locations in southern Turkey during 2013-2015.
(Ministry of Food, Agriculture and Livestock, 2016). Of 10,295 marked adults, 707 were recaptured. Overall sex ratio among the marked individuals was 1.55 (male:female), with a range of $0.37-1.76$ across all locations and years.

Population sizes as estimated by CAPTURE analyses were highest in spring and lowest in autumn, with a slight decrease across years (Fig. 1). Apparent survival rates $(\phi)$ averaged 0.35 for juveniles and 0.56 for adults, and mean fecundity $\left(F \times S_{\mathrm{a}}\right)$ was 0.38 (Table 1$)$. The eigenvalue of the resulting stage matrix is 0.74 , corresponding to a $26 \%$ decline per year (the eigenvalue gives the proportional change in population size from one year to the next, as in $N(t+1) / N(t)$, with 1.0 corresponding to no change, and values $<1$ corresponding to population decline). This is a steeper decline than the population reduction based on capture estimates, which was c. $20 \%$ per year. The difference is probably because of emigration (i.e. the apparent survival underestimating true survival). Using the $5 \%$ upper bound of emigration that we assumed, the stage matrix becomes (Table 1):

$$
\begin{array}{ll}
0.000 & 0.381 \\
0.400 & 0.612
\end{array}
$$

The eigenvalue of this matrix is 0.802 , which is more consistent with the observed declines. Thus, we used the above matrix, with values corrected for emigration, for further analysis. Even with this correction, the 10-year population reduction would be c. $89 \%\left(1-0.802^{10}\right)$, and 3 -generation (c. 13-year) reduction would be $>90 \%$. Stochastic simulations estimated a $95.6 \%$ risk of extinction in 50 years, with a median time to extinction of 36 years, and an almost $100 \%$ risk of the population declining to $<1$,000 individuals.

The analysis of capture efficiency resulted in estimates of survival rate in a non-harvested population averaging 0.55 for juveniles and 0.85 for adults (after correction for emigration; Table 2). The resulting stage matrix has an eigenvalue of 1.115 , corresponding to an $11.5 \%$ increase per year in a non- harvested population. This is a reasonable value, considering that the population must be below carrying capacity as a result of the effects of past harvest, so a moderate population increase in the absence of harvest would be expected. However, the growth rate may be higher at lower densities, which would influence the estimation of harvest impact. Simulations with harvest mortality $(H)$ of $0-0.3$ showed that risk of population decline increases with harvest rate, reaching c. $100 \%$ when $H>0.2$, and the total harvest over the 50-year simulated period reaches a maximum at $\mathrm{c}$. $H=0.05$, and declines with increasing $H$ above this value (Fig. 2).

\section{Harvesting history and export statistics}

Frog harvest and export data statistics have been recorded by TÜİK since 1991, but the records are not complete until 2002 and inconsistent thereafter. This is probably because of inaccurate and incomplete information provided by the harvesters and export companies. Nevertheless, it is clear that Turkey plays an important role in the frog trade, especially to European countries. In 2017 alone, nearly $350 \mathrm{t}$ of frogs were exported, worth $>$ USD 3.5 million. During 1991-2017 frog harvests from Seyhan and Ceyhan Deltas comprised $34.4 \%$ (nearly $4,500 \mathrm{t}$ ) of the total harvest in Turkey (Fig. 3). Since 2012 the average harvest from this area was $327 \mathrm{t}$ per year (TÜIKK Fisheries Statistics, 2018). Based on the mean weight of frogs in our study, this harvest represents c. 17 million frogs per year from the Ceyhan-Seyhan region.

Frogs are also farmed, where they are raised in manmade structures and supplemented with feed. This is a relatively new business in Turkey, with c. 12 farms established within the last decade (Kürüm, 2015). These farms contribute an average of 45 tons annually to frog exports, with a total of 180 tons during 2014-2017 (TÜİK Fisheries Statistics, 2018). 
TABLE 2 Estimation of harvest mortality and the parameters of the matrix model for a non-harvested population.

\begin{tabular}{|c|c|c|c|c|c|}
\hline \multirow[b]{2}{*}{ Year } & \multicolumn{2}{|c|}{ Capture or harvest } & \multicolumn{2}{|l|}{ Survival rates ${ }^{1}$} & \multirow{2}{*}{$\begin{array}{l}\text { Reproduction } \\
F \times S_{\mathrm{a}}^{\prime}{ }^{4}\end{array}$} \\
\hline & $T^{2}$ & $H^{3}$ & Juvenile $\left(S_{\mathrm{j}}^{\prime}\right)$ & Adult $\left(S_{\mathrm{a}}^{\prime}\right)$ & \\
\hline 2013 & 0.420 & 0.296 & 0.611 & 0.818 & \\
\hline 2014 & 0.415 & 0.293 & 0.468 & 0.866 & 0.753 \\
\hline 2015 & 0.434 & 0.303 & 0.413 & 0.714 & 0.329 \\
\hline Mean $^{5}$ & & & 0.497 & 0.800 & 0.541 \\
\hline Mean, corrected for emigration ${ }^{6}$ & & & 0.547 & 0.850 & \\
\hline Standard deviation & & & 0.102 & 0.078 & 0.300 \\
\hline
\end{tabular}

${ }^{1} S^{\prime}=S /(1-H)$, an estimate of the apparent survival rate in a non-harvested population, where $S$ values are from Table 1.

${ }^{2}$ Number of captured individuals, divided by the total population size as estimated with CAPTURE.

${ }^{3} H=T /(1+T)$, an estimate of the proportion of individuals of a pre-harvest population that are killed by harvest (i.e. harvest mortality).

${ }^{4} F \times S_{\mathrm{a}} \times\left(S_{\mathrm{a}}^{\prime} / S_{\mathrm{a}}\right)$ where $F \times S_{\mathrm{a}}$ is from Table 1 (thus, assuming the same $F$ as in a harvested population).

${ }^{5}$ Mean apparent survival rate and mean fecundity in a non-harvested population.

${ }^{6}$ Upper bound of average survival rate in a non-harvested population, corrected by assuming $5 \%$ emigration (see text for details).

Harvesters must have a licence from the provincial Food, Agriculture and Livestock authority (Kürüm, 2015). Most harvesters have a low income, no permanent job and no social benefits (authors, pers. obs., 2014; Akın \& Bilgin, 2010). For some, frog harvesting is their main source of income; it does not require capital investment. Other harvesters are seasonal farm workers who hunt frogs for additional income. Harvesters hunt at night, in groups of 3-4. Only one
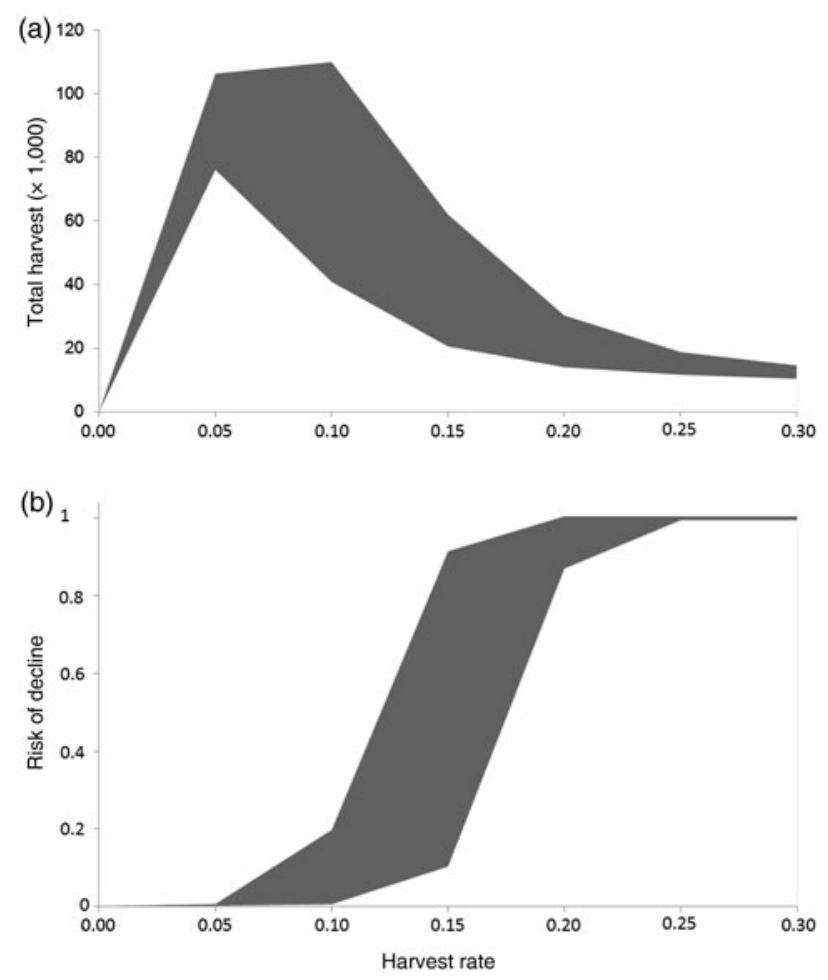

FIG. 2 The effect of harvest rate on (a) total harvest over 50 years (thousands of individuals), and (b) probability that the population will fall below 1,00o individual frogs any time in the next 50 years, based on stochastic simulations. The gray shading indicates uncertainty that results from the type of density dependence model used (ceiling or contest). in a group has a hunting licence, which is legally sufficient. Price per kg depends on demand, but is usually TRY $3^{-12}$ (USD o.6-2.6). Companies offer the harvesters the highest price (12 TRY/kg) in the winter. One person can typically harvest $20-39 \mathrm{~kg}$ of frogs per night, but sometimes the harvest can be up to $60 \mathrm{~kg}$. Harvesters use flashlights or pressurized paraffin lamps as a light source (Supplementary Plate 1). One person holds the light and others collect the frogs by hand or net and place them in cloth bags. As the export companies do not buy dead frogs, harvesters keep bags of 3-4 kg (Supplementary Plate 2) in a cool place until the end of a night's harvest, and they are then despatched for processing and packing (Supplementary Plate 3).

\section{Discussion}

Our study shows that Anatolian water frogs are harvested at high and unsustainable levels in southern Turkey. Simulations of the harvested population dynamics indicate a $90 \%$ risk of extinction within 50 years, with a probable year of extinction in c. 2032. Simulations show that if harvest mortality was to be reduced from the current estimated value of c. 0.3 ( $H$ in Table 2) to c. 0.05 , not only would the risk of a population crash decline sharply but the total expected harvest over the next 50 years would be much higher (Fig. 2). This suggests that current harvest levels are probably unsustainable and could lead to extirpations of the harvested populations. Because we do not have data on the proportion of populations that are harvested at these levels, we cannot make projections about the status of the species in this region. However, if harvested populations become extirpated, harvest pressure could shift to, and threaten, other populations that are currently stable. Our results also show that enforcing strict harvest regulations would not only protect these frog populations but also help the local economy by providing a source of income that is sustainable in the long term. 


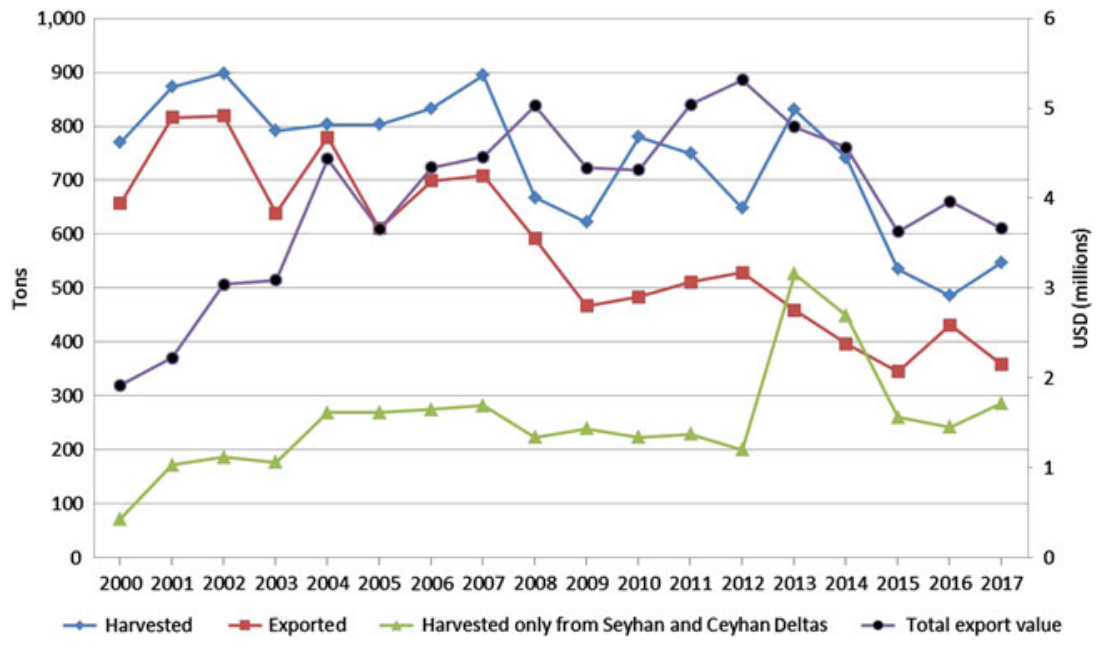

FIG. 3 Total harvest, total of harvest exported, total harvest in the Seyhan and Ceyhan Deltas, and the total export value during 2000-2017 (TÜİK Fisheries Statistics, 2018).
There are few demographic models of amphibian populations because of lack of data to estimate many model parameters including, in our study, information on harvest rates across the landscape, demographic rates from unharvested populations, emigration and immigration rates, and direct estimates of annual fecundity. In addition, the short duration and restricted spatial scale of our study decreases the reliability of model results. Nevertheless, the drastic declines projected for harvested populations suggest that the current harvest rates are unsustainable. Long-term mark-recapture and monitoring over larger areas would provide better data for estimating model parameters.

Large-scale collections of frogs from the wild not only reduce population sizes (Schlaepfer et al., 2005; Altherr et al., 2011), but also disturb habitats (Goode et al., 2004), introduce exotic pests and parasites (Franke \& Telecky, 2001), spread diseases to native fauna (Daszak et al., 1999), and reduce ecological control of mosquito populations (Raghavendra et al., 2008; Mohneke, 2011) and agricultural pests (Abdulali, 1985; Kusrini, 2005). Thus, addressing the impacts of overharvesting is a priority for conservation (Gilbert et al., 2012).

Another concern is that exported live frogs may be sold in pet shops in countries outside the species' native range, and could in some cases become invasive species. Anatolian frogs have already entered Europe via commercial trade, and are expected to invade Western and Central Europe further, with risks of large-scale hybridization and introgression (Holsbeek et al., 2008). Annual global frog consumption is $0.8-3.2$ billion individuals (Gratwicke et al., 2010), and its effects show a particular spatio-temporal pattern. As a country's frog populations decline as a result of overharvesting, harvest bans shift the pressure to other countries. After frog harvesting was banned in France and Romania, exports of wild-caught frogs from India and Bangladesh increased, leading to population declines and subsequent harvest bans in these countries (Török, 1999; Kriger \& Hero, 2009; Altherr et al., 2011). This caused the harvest pressure to shift once again, this time to Indonesia and China, which are now experiencing this extinction domino effect (Altherr et al., 2011), with many frog species at risk of extirpation and extinction (Carpenter et al., 2007; Warkentin et al., 2008; Chan et al., 2014).

Our study provides insights into the position of Turkey in this extinction domino line. Frogs in Turkey are harvested almost exclusively from the wild, and the country provides c. $4 \%$ of Europe's frog imports (Altherr et al., 2011). Typical incomes from frog harvesting are low, but a main source of income for most of the harvesters. Economic dependence on the harvest increases the pressure on frog populations, and the ecosystems of which they are a part. Unsustainable and unregulated harvest also increases economic inequalities. The results of our simulations show that the extremely high rates of harvest will result in the extirpation of these frog populations and thus remove the harvesters' livelihoods.

A challenge for the regulation of the frog harvest in Turkey is taxonomic uncertainty. The genus Pelophylax (Rana) is a poorly identified species complex comprising genetic, phylogenetic and ecological forms (Plötner, 2005; Akın et al., 2010; Plötner et al., 2010). Genetic analyses show there could be cryptic species in Anatolia with similar morphology (Akın et al., 2010). Systematical uncertainty, lack of knowledge of the distribution of genetic lineages, and the morphological similarity of Anatolian water frogs (Plötner \& Ohst, 2001; Akın et al., 2010; Plötner et al., 2010) hinder species identification through morphology. The frog-exporting companies turn this incognizance into an opportunity, labelling all frogs as Pelophylax esculentus, a hybrid form known as 'edible frog', which is native to Europe but absent in Turkey. In addition to the need for clarification of the systematics of Anatolian water frogs using genetic methods, genetic identification is required for certification during export.

Export data for the Seyhan and Ceyhan Deltas were obtained from frog processing companies, which receive 
harvested frogs from this region, from other parts of Turkey and from neighbouring Syria (harvesters, pers. comm., 2014). Therefore, the impact of the overharvest we have identified may not be immediately reflected in export figures. Our research demonstrates that overharvesting damages wild frog populations but despite the efforts of governmental agencies to enforce existing regulations, harvesting threatens frog populations not only in our study area, but throughout Anatolia. Scientific findings are rarely used for regulatory decision-making on harvesting, farming and export of frogs.

Based on our findings, we conclude that further harvest restrictions are essential for the sustainability of Anatolian water frog populations. Considering its importance for livelihoods, a complete ban on harvesting wild frogs is, however, infeasible, and therefore we make five recommendations:

Ban harvest during the mating season The current harvest ban is during 1 May-30 June, but mating of water frogs takes place from late winter to early summer in Turkey, depending on the region (authors, unpubl. data). Because of its mild Mediterranean climate, mating occurs earlier in our study area, during 15 February-15 April. Therefore the harvest ban needs to be adjusted to regional conditions.

Obligatory training for all harvesters Although rarely conducted in Turkey, training is required to provide harvesters with basic species knowledge and awareness of regulations and to improve the sustainability of harvesting.

Quota based systems Limiting each export firm's harvest during a given period could be an effective way to limit harvest because each harvest location is controlled by a single exporter firm at any one time. Inspections should be at the processing and export locations as well as in the harvest locations in the field. This would facilitate sustainable harvest by both preventing overharvest in the field and by controlling the total number of frogs processed. Alternatively, harvest locations could be closed every other year to relieve the pressure on individual populations.

Effective enforcement of size limits If the $30 \mathrm{~g}$ minimum size restriction could be applied effectively, the number of frogs collected would decrease markedly. As for a quota system, it would be easier to enforce this limit at the processing and export stages.

Frog farming The number of farmed frogs exported is currently limited but farming could be encouraged by the government as an alternative to collecting wild frogs.

Sustainable rates of wild harvest depend on the abundance and demography of populations, the behaviour and life-history characteristics of a species (Schlaepfer et al., 2005), and socio-economic factors (Klemens \& Thorbjarnarson, 1995; Reynolds et al., 2001), and thus determining sustainable harvesting rates is complex. Our data and analysis provide the initial steps for this process.

Author contributions Study design and fieldwork: KÇ, DA, MA, YB, OC, İBİ; data analysis and writing: KÇ, HRA, CCB, YB, ÇA, EÜ, DA, MY, CVT.

Acknowledgements This study was financially supported by TUBITAK (The Scientific and Technological Research Council of Turkey, Project number: 112T913) and EBILTEM (Ege University Science and Technology Centre, Project number: 2013/BIL/013). We thank Dr. Jörg Plötner for early discussions and Mr. Vahdettin Kürüm for providing frog trade statistics.

\section{Conflicts of interest None.}

Ethical standards This research abided by the Oryx guidelines on ethical standards and the protocol was approved by the Laboratory Animals Ethical Committee at Ege University, Turkey (Decision No. 2012/29).

\section{References}

A bdulali, H. (1985) On the export of frog legs from India. Journal of the Bombay Natural History Society, 2, 347-375.

АкС̧АкАYA, H.R. (1991) A method for simulating demographic stochasticity. Ecological Modelling, 54, 133-136.

Aкс̧акау , H.R. (2013) RAMAS Metapop: Viability Analysis for Stage-structured Metapopulations. Version 6.o. Applied Biomathematics, Setauket, USA.

Aкс̧акаya, H.R., Mills, G. \& Doncaster, C.P. (2007) The role of metapopulations in conservation. In Key Topics in Conservation Biology (eds D.W. Macdonald \& K. Service), pp. 64-84. Blackwell, Oxford, UK.

Akın, Ç. \& Bilgin, C.C. (2010) Preliminary Report on the Collection, Processing and Export of Water Frogs in Turkey. (Presented to KKGM). ODTÜ, Ankara, Turkey. [in Turkish]

Akin, Ç., Bilgin, C.C., Beerli, P., Westaway, R., Ohst, T., Litvinchuk, S.N. et al. (2010) Phylogeographic patterns of genetic diversity in eastern Mediterranean water frogs were determined by geological processes and climate change in the Late Cenozoic. Journal of Biogeography, 37, 2111-2124.

Alford, R.A. \& Richards, S.J. (1999) Global amphibian declines: a problem in applied ecology. Annual Review of Ecology, Evolution and Systematics, 30, 133-165.

Altherr, S., Goyenechea, A. \& Schubert, D. (2011) Canapés to Extinction - the International Trade in Frogs' Legs and its Ecological Impact. A report by Pro Wildlife, Defenders of Wildlife and Animal Welfare Institute (eds), Munich, Germany, and Washington, DC, USA.

Armstrong, P., Young, C. \& McKeown, D. (1990) Ethyl chloride and venepuncture pain: a comparison with intradermal lidocaine. Canadian Journal of Anaesthesia, 37, 656-658.

Baker, S.E., Cain, R., van Kesteren, F., Zommers, Z.A., D'Cruze, N. \& Macdonald, D.W. (2013) Rough trade: animal welfare in the global wildlife trade. BioScience, 63, 928-938.

Boone, M.D. \& Bridges, C.M. (2003) Effects of carbaryl on green frog (Rana clamitans) tadpoles: timing of exposure versus multiple exposures. Environmental Toxicology and Chemistry, 22, 2695-2702.

Carpenter, A.I., Dublin, H., Lau, M., Syed, G., McKay, J.E. \& Moore, R.D. (2007) Over-harvesting. In Amphibian Conservation Action Plan (eds C. Gascon, J.P. Collins, R.D. Moore, D.R. Church, 
J.E. McKay, \& J.R. Mendelson), pp. 26-31. IUCN, Gland, Switzerland, 21-31.

Chan, H.K., Shoemaker, K.T. \& Karraker, N.E. (2014) Demography of Quasipaa frogs in China reveals high vulnerability to widespread harvest pressure. Biological Conservation, 170, 3-9.

Chan, H.K., Zhang, H., YAng, F. \& Fischer, G. (2015) Improve customs systems to monitor global wildlife trade. Science, 348, 291-292.

ÇıçeK, K. (2009) Population Dynamics of Rana macrocnemis Boulenger, 1885 (Anura:Ranidae) inhabiting Uludă̆ (Bursa). MSc thesis, Ege University, İzmir, Turkey.

Çıçek, K., Mermer, A. \& Tok, C.V. (2011) Population dynamics of Rana macrocnemis Boulenger. 1885 at Uludağ. Western Turkey (Anura: Ranidae). Zoology in the Middle East, 53, 41-6o.

Cooch, E.G. \& White, G.C. (2017) Program MARK: a Gentle Introduction. 1082 pp. phidot.org/software/mark/docs/book [accessed 13 November 2018].

CORMACK, R.M. (1964) Estimates of survival from the sighting of marked animals. Biometrika, 51, 429-438.

Daszak, P., Berger, L., Cunningham, A.A., Hyatt, A.D., Green, D.E. \& SPEARE, R. (1999) Emerging infectious diseases and amphibian population declines. Emerging Infectious Diseases, 5, 735-748.

Daszak, P., Cunningham, A.A. \& Hyatt, A.D. (2003) Infectious disease and amphibian population declines. Diversity and Distributions, 9, 141-150.

Franke, J. \& Telecky, T.M. (2001) Reptiles as pets: an examination of the trade in live reptiles in the United States. Journal of International Wildlife Law and Policy, 4, 315-317.

Gerson, H. (2012) International trade in Amphibians: a customs perspective. Alytes, 29, 103-115.

Gibbons, J.W., Scott, D.E., Ryan, T.J., Buhlmann, K.A., Tuberville, T.D., Metts, B.S. et al. (2000) The global decline of reptiles, déjà vu amphibians. BioScience, 50, 653-666.

Gilbert, M., Bickford, D., Clark, L., Johnson, A., Joyner, P.H., KeAtTs, L.O. et al. (2012) Amphibian pathogens in Southeast Asian frog trade. EcoHealth, 9, 386-398.

Goode, M.J., Swann, D.E. \& Schwalbe, C.R. (2004) Effects of destructive collecting practices on reptiles: a field experiment. Journal of Wildlife Management, 68, 429-434.

Gratwicke, B., Evans, M.J., Jenkins, P.T., Kusrini, M.D., Moore, R.D., SEVIN, J. et al. (2010) Is the international frog legs trade a potential vector for deadly amphibian pathogens? Frontiers in Ecology and the Environment, 8, 438-442.

Holsbeek, G., Mergeay, J., Hotz, H., Plötner, J., Volckaert, F.A.M. \& De Meester, L. (2008) A cryptic invasion within an invasion and widespread introgression in the European water frog complex: consequences of uncontrolled commercial trade and weak international legislation. Molecular Ecology, 17, 5023-5035.

Houlahan, J.E., Findlay, C.S., Schmidt, B.R., Meyer, A.H. \& KUZMin, S.L. (2000) Quantitative evidence for global amphibian population declines. Nature, 404, 752-755.

Jolly, G.M. (1965) Explicit estimates for capture-recapture data with both death and immigration stochastic model. Biometrika, $52,225-247$.

Karesh, W.B., Cook, R.A., Bennett, E.L. \& Newcomb, J. (2005) Wildlife trade and global disease emergence. Emerging Infectious Diseases, 11, 1000-1002.

Kats, L.B. \& Ferrer, R.P. (2003) Alien predators and amphibian declines: review of two decades of science and the transition to conservation. Diversity and Distributions, 9, 99-110.

Kiesecker, J.M., Blaustein, A.R. \& Belden, L.K. (2001) Complex causes of amphibian population declines. Nature, 410, 681-684.

Klemens, M.W. \& Thorbjarnarson, J.B. (1995) Reptiles as a food source. Biodiversity and Conservation, 4, 281-298.
Kriger, K.M. \& Hero, J.M. (2009) Chytridiomycosis, amphibian extinctions and lessons for the prevention of future panzootics. EcoHealth, 6, 6-10.

KÜRUM, V. (2015) Statistics of Frog Trade in Turkey. Republic of Turkey Ministry of Agriculture and Forestry General Directorate of Fisheries and Aquaculture, Ankara, Turkey. [in Turkish]

KusRINI, M.D. (2005) Edible frog harvesting in Indonesia: evaluating its impacts and ecological context. MSc thesis, School of Tropical Biology, James Cook University, Australia.

Ministry of Food, Agriculture and Livestock (2016) Bulletin 4/1. mevzuat.gov.tr/Metin.Aspx?MevzuatKod=9.5.22750\&MevzuatIliski= o\&sourceXmlSearch=ticari\%2oama\%C3\%A7l\%C4\%B1 [accessed 1 January 2019]. [in Turkish]

Mohneke, M. (2011) (Un)sustainable use of frogs in West Africa and resulting consequences for the ecosystem. MSc thesis,

Mathematisch-Naturwissenschaftliche Fakultät, HumboldtUniversität zu Berlin, Berlin, Germany.

Musing, L., Norwisz, M., Kloda, J. \& Kecse-Nagy, K. (2018) Wildlife Trade in Belgium: an Analysis of CITES Trade and Seizure Data. TRAFFIC and WWF, Cambridge, UK.

Otis, D.L., Burnham, K.P., White, G.C. \& Anderson, D.R. (1978) Statistical inference from capture data on closed animal populations. Wildlife Monographs, 62, 3-135.

Pavajeau, L., Zippel, K.C., Gibson, R. \& Johnson, K. (2008) Amphibian Ark and the 2008 year of the frog campaign. International Zoo Yearbook, 42, 24-29.

PlÖtNeR, J. (2005) Die westpaläarktischen Wasserfrösche: von Märtyrern der Wissenschaft zur biologischen Sensation. Laurenti-Verlag, Bielefeld, Germany.

Plötner, J. \& OHSt, T. (2001) New hypothesis of the western Palearctic water frog complex (Anura: Ranidae). Mitteilungen aus dem Zoologischen Museum in Berlin, 77, 5-21.

Plötner, J., Uzzell, T., Beerli, P., Akin, Ç., Bilgin, C.C., Haefeli, C. et al. (2010) Genetic divergence and evolution of reproductive isolation in eastern Mediterranean water frogs. In Evolution in Action. Case Studies in Adaptive Radiation, Speciation and the Origin of Biodiversity. Special Volume from the SPP 1127 "Radiations Genesis of Biological Diversity” of the DFG (ed. M. Glaubrecht), pp. 373-403. Springer, Heidelberg, Berlin, Germany.

Polishchuk, D., Gehrmann, R. \& Tan, V. (2012) Skin sterility after application of ethyl chloride spray. Journal of Bone \& Joint Surgery, 94, 118-120.

Raghavendra, K., Sharma, P. \& Dash, A.P. (2008) Biological control of mosquito populations through frogs: opportunities and constrains. Indian Journal of Medical Research, $128,22-25$.

Reynolds, R.E., Shaffer, T.L., Renner, R.W., Newton, W.E. \& B A T, B.D.J. (2001) Impact of the conservation reserve program on duck recruitment in the U.S. Prairie Pothole Region. Journal of Wildlife Management, 65, 765-780.

Scheffers, B.R., Oliveira, B.F., Lamb, I. \& Edwards, D.P. (2019) Global wildlife trade across the tree of life. Science, 366, 71-76.

Schlaepfer, M.A., Hoover, C. \& Dodd, Jr, C.K. (2005) Challenges in evaluating the impact of the trade in amphibians and reptiles on wild populations. BioScience, 55, 256-264.

Seber, G.A.F. (1965) A note on the multiple recapture census. Biometrika, 52, 249-259.

Smith, M. \& Green, D. (2005) Dispersal and the metapopulation paradigm in amphibian ecology and conservation: are all amphibian populations metapopulations? Ecography, 28, 110-128.

Smith, R.K., Meredith, H. \& Sutherland, W.J. (2018) Amphibian conservation. In What Works in Conservation 2018 (eds W.J. Sutherland, L.V. Dicks, N. Ockendon, S.O. Petrovan \& R.K. Smith), pp. 9-65. Open Book Publishers, Cambridge, UK. 
Sodhi, N.S., Koh, L.P., Brook, B.W. \& NG, P.K.L. (2004) Southeast Asian biodiversity: an impending disaster. Trends in Ecology and Evolution, 19, 654-660.

Stuart, S.N., Chanson, J.S., Cox, N.A., Young, B.E., Rodrigues, A.S.L., Fischman, D.L. et al. (2004) Status and trends of amphibian declines and extinctions worldwide. Science, 306, 1783-1786.

Török, Z. (1999) Ghid pentru descrierea ariilor de importanță herpetofaunistică din România. Probleme de Ecologie Teoretică şi Aplicată în România - Direcții Actuale, No. 2. Editura Aves, Tulcea Romania.

Tüik (Turkish Statistical Institute) Fisheries Statistics (2018) Turkish Statistical Institute, Ankara, Turkey. turkstat.gov.tr/Pre TabloArama.do? metod=search\&araType=vt [accessed 1 January 2019].
Warkentin, I.G., Bickford, D., Sodhi, N.S. \& Bradshaw, C.J.A. (2008) Eating frogs to extinction. Conservation Biology, 23, 1056-1059.

White, G.C. \& Burnham, K.P. (1999) Program MARK: survival estimation from populations of marked animals. Bird Study, $46,120-138$.

White, G.C., Anderson, D.R., Burnham, K.P. \& Otis, D.L. (1982) Capture-Recapture and Removal Methods for Sampling Closed Populations. Los Alamos National Laboratory Rep. LA-8787-NERP, Los Alamos, USA.

Worm, B., Barbier, E.B., Beaumont, N., Duffy, J.E., Folke, C., HALPERN, B.S. et al. (2006) Impacts of biodiversity loss on ocean ecosystem services. Science, 314, 787-790. 